\title{
UPAYA HUKUM PT BANK RAKYAT INDONESIA (PERSERO) TBK UNIT AMLAPURA TERHADAP DEBITUR YANG WANPRESTASI DALAM USAHA MIKRO
}

\author{
I Kadek Adi Payana, I Nyoman Putu Budiartha, Ni Made Puspasutari Ujianti \\ Fakultas Hukum Universitas Warmadewa, Denpasar - Bali, Indonesia
}

\begin{abstract}
Abstrak
Pembangunan pada bidang ekonomi merupakan penggerak utama pembangunan, Usaha Mikro memainkan peranan penting dalam pembangunan dan pertumbuhan ekonomi, tidak hanya di negara-negara berkembang namun juga di negara maju. Penelitian ini mengkaji dua isu terkait kegiatan ekonomi dari sudut pandang hukum: pertama, terkait wanprestasi dan akibat hukumnya dalam perjanjian kredit usaha rakyat mikro pada, dan yang kedua, terkait dengan pelunasan hutang debitur d a lam perjanjian kredit. Kajian ini dilakukan pada Bank BRI. Metode Penelitian yang digunakan adalah penelitian hukum empiris. Data diolah dan dianalisis secara kualitatif. Tujuan analisa tersebut untuk menekan seminimal mungkin resiko terjadinya kredit macet. Selanjutnya memilahmilah permohonan kredit yang diajukan berdasarkan plafon pinjaman. Hasil menunjukkan pada PT. Bank BRI Kantor Unit Amalapura pemberian kredit KUR Mikro kepada debitur dijamin oleh penjamin (PT Askrindo), sebesar 70\% dari platfond kredit dan 30\% dari bank apabila debitur wanprestasi dan tidak ada jamnian tambahan sesuai dengan ketentuan Surat Edaran Nose: S.8a-DIR/ADK/02/2008. Namun setelah penjaminan diberikan oleh penjamin kepada kreditur, nantinya hak untuk menagih pelunasan utang debitur beralih kepada penjamin (Subrogasi), sehingga debitur tetap memiliki kewajiban untuk melunasi utangnya. Upaya hukum yang dilakukan oleh kreditur terhadap debitur yang tidak dapat melakukan pelunasan hutangnya dalam hal terjadi kredit macet ialah mengidentifikasi sedini mungkin terjadinya kredit macet dan mengintensifkan penagihan, melakukan musyawarah mufakat untuk menemukan jalan keluar yang dikehendaki kedua belah pihak (win-win solution). Selain upaya hukum tersebut, ketentuan Pasal 1131 KUH-Perdata tentang Jaminan Umum dapat digunakan sebagai landasan pelunasan utang debitur dengan mengajukan gugatan perdata ke Pengadilan Negeri.
\end{abstract}

Kata Kunci: Kredit; Perjanjian; Wanprestasi

\begin{abstract}
Development in the economic sector plays as the main driving aspect of development. Micro Business plays a crucial role in development and economic growth, not only in developing countries but also in developed countries. This study examines two issues related to economic activities from a legal point of view: first, relating to defaults and their legal consequences in micro business credit agreements, and secondly, related to repayment in credit agreements. This study was conducted at BRI (Bank Rakyat Indonesia). The research method used was empirical legal research. The data were processed and analysed qualitatively, the purpose of which to minimize the risk of bad credit. Then, I sorted out the loan application submitted based on the loan ceiling. The results show at PT. Bank BRI, the Office of Almapura Unit, the giving Micro KUR credit to debtors guaranteed by the guarantor (PT Askrindo), amounting to $70 \%$ of the credit platform and $30 \%$ of the bank if the debtor defaults and there are no additional guarantees in accordance with the provisions of the Circular Nose: S.8-DIR/ADK/02/2008. However, after the guarantee is given by the guarantor to the creditor, later the right to collect the debtor's debt repayment is transferred to the guarantor (subrogation), so the debtor still has the obligation to repay their debt. Legal remedies undertaken by creditors against debtors who cannot repay their debts in the event of bad credit is to identify as early as possible the occurrence of bad credit and intensify collection, conduct consensus agreement to find a solution that is desired by both parties (win-win solution). In addition to these legal remedies, the provisions of Article 1131 of the Civil Code regarding General Security can be used as a basis for the repayment of the debtors' debts by submitting a civil suit to the District Court.
\end{abstract}

Keywords: Credit; Agreement; Default 


\section{PENDAHULUAN}

Manusia melanjutkan hidup ditentukan dari caranya mempunyai persepsi (memandang, menghayati dan memahami) dirinya sendiri dan nilai-nilai yang didukungnya (Wilee \& Davis, 1976). Dalam realitanya tampak bahwa manusia ialah realita berupa mahluk hidup, yang memperlihatkan dua aspek yang tidak dapat dipisahkan satu dari yang lainnya. Aspek yang satu sebagai manusia individual sedangkan aspek lainnya sebagai masyarakat atau kebersamaan dengan manusia-manusia individu lainnya (Ibrahim \& Sewu, 2007; Kraft et al., 2002)

Dalam masyarakat yang teratur setiap manusia sebagai anggota masyarakat harus memperhatikan norma atau kaidah, atau peraturan hidup yang ada dan hidup dalam masyarakat, sehingga masyarakat yang tentram dan bersahaja bisa diwujudkan, demikian juga pembangunan di masyarakat bisa dilangsungkan, karena tanpa didukung oleh situasi yang kondusif maka mustahil pembangunan bisa dijalankan dkk., 2012). Oleh karena itu untuk melangsungkan pembangunan di suatu Negara, ketertiban masyarakat yang paling pertama yang harus diwujudkan.

Pembangunan pada bidang ekonomi merupakan penggerak utama pembangunan, namun pembangunan ekonomi harus disertai upaya saling memperkuat, terkait, serta terpadu dengan pembangunan di bidang lainnya (Solikatun dkk., 2014). Misalnya pembangunan ekonomi dengan hukum mempunyai hubungan timbal balik. Dalam membangun suatu usaha mikro diperlukan modal usaha yang diperoleh dari peminjaman suatu modal usaha yang diperoleh melalui pihak tertentu (Anggraeni dkk., 2013). Bagian terpenting dari pembangunan usaha mikro adalah peminjaman modal usaha yang diperoleh dari kredit yang di dapatkan dari suatu bank.

Dalam usaha-usaha mikro, hal yang sering sekali terjadi dalam hubungan debitur dengan kreditur ialah wanprestasi, sebuah bentuk pelaksanaan kewajiban yang tidak dipenuhi atau dengan kata lain ingkar janji. Bentuk wanprestasi yang dilakukan debitur yaitu debitur kredit usaha mikro terlambat melaksanakan apa yang telah di perjanjikan maka tenggang waktu yang di perjanjiakan melewati batas jatuh temponya sehingga tidak memenuhi apa dengan yang diperjanjikan oleh kedua belah pihak yang dapat mengakibatkan seorang wanprestasi, maka jaminan dengan sendirinya boleh menjadi hak kreditur (Pramudyawardani, 2010). Dengan demikian dapat diketahui bahwa, debitur wanprestasi menjadi masalah pokok perjanjian kredit usaha mikro. Dalam hal ini lembaga perbankan sebagai pihak yang memberikan kredit pada usaha mikro, mengakibatkan terjadinya indikasi wanprestasi oleh debitur yang berakibat kerugian pada bank kredit itu sendiri.

Sejumlah kajian tentang terjadinya wanprestasi, penyebab wanprestasi, dan cara penyelesaian kredit yang memiliki wanprestasi telah diluncurkan (Ackah \& Vuvor, 2011 Anggraeni et al., 2013; Aryastini dkk., 2018; Apriani, 2018). Dari penelitian-penelitian ini belum terlihat ada sentuhan terhadap upaya hukum bank atas tindakan perbuatan wanprestasi yang terjadi pada usaha mikro dan bagaimana seorang yang melakukan wanprestasi dapat menyelesaikan permasalahan dengan cara melunasinya. Penelitian ini menyajikan pendekatan penyelesaian masalah terkait wanprestasi dengan pendekatan hukum pelindung upaya yang dilakukan oleh bank supaya debitur yang wanprestasi dapat melunasi kewajibannya. Oleh karena itu, penelitian ini mengungkap jawaban atas dua pertanyaan dalam dunia bisnis yang kerap kali mengalami wanpretasi: 1. Bagaimanakah akibat hukum debitur wanprestasi dalam perjanjian kredit usaha rakyat mikro pada PT. Bank BRI Kantor Unit Amlapura? 2. Apakah Upaya hukum yang dilakukan oleh kreditur terhadap debitur yang tidak dapat melakukan pelunasan hutangnya?

\section{METODE PENELITIAN}

Penelitian ini merupakan penelitian hukum normatif, yaitu dengan mengkaji hukum tertulis dari berbagai aspek yaitu aspek teori, sejarah, filosofi, perbandingan, struktur dan komposisi, lingkungan dan materi konsistensi penjelasan umum dan pasal demi pasal, formalitas dan kegunaan mengikat suatu Undang-Undang serta bahasa hukum yang digunakan (Mercuro, 1986). Sedangkan Pendekatan yang digunakan dalam penelitian ini adalah pendekatan perundang- undangan dan pendekatan konseptual dikaitkan dengan permasalahan dalam penelitian ini. Untuk mendapatkan hasil yang komprehensif, penelitian ini juga ditunjang dengan wawancara dalam menggali informasi dari pihak PT. Bank BRI. Undang yang mengatur tentang Usaha Mikro Kecil dan Menengah ditemukan. Beberapa literatur terkait usaha mikro dan wanprestasi juga diperoleh untuk menunjukkan eksistensi dan perkembangan wanprestasi, khususnya terkait usaha-usaha mikro. Kemudian, wawancara teruka dilakukan dengan 
manager BRI di Bali. Data dinalisis dengan metode dan teknik analisis deskriptif. Kemudian simpulan ditarik menurut hasil yang ditemukan.

\section{HASIL PENELITIAN DAN PEMBAHASAN Wanprestasi dan Akibat Hukumnya Dalam Perjanjian Kredit Usaha Rakyat Mikro Pada PT. Bank BRI}

KUR adalah program yang dicanangkan oleh pemerintah namun sumber dananya berasal sepenuhnya dari dana bank. Pemerintah memberikan penjaminan terhadap risiko KUR sebesar 70\% sementara sisanya sebesar $30 \%$ ditanggung oleh bank pelaksana. Penjaminan KUR diberikan dalam rangka meningkatkan akses UMKMk pada sumber pembiayaan dalam rangka mendorong pertumbuhan ekonomi nasional (Ramandhana dkk., 2018). Resiko KUR sebesar 70\% dijamin oleh pemerintah melalui PT. Asuransi Kredit Indonesia (Askrindo).

Perikatan lahir karena adanya suatu perjanjian terlebih dahulu yang dilakukan oleh para pihak. Selain itu ada juga perikatan yang lahir karena memang sudah diatur dalam ketentuan undang- undang. Jadi pihak kreditur merupakan pihak yang sangat menghendaki agar perikatan itu dapat dipenuhi secara sempurna dengan sukarela sesuai dengan isi perikatan yang dibuat oleh para pihak. Namun kemungkinan harapan itu tidaklah dapat berjalan sebagaimana dikehendaki sebab kemungkinan dapat terjadi seorang debitur itu cidera janji atau lalai untuk mernenuhi kewajibannya itu. Debitur yang sama sekali tidak melakukan prestasi, atau melakukan prestasi yang keliru atau terlambat melakukan prestasi dapat dikatakan wanprestasi.

Wanprestasi atau tidak dipenuhinya janji dapat terjadi baik karena sengaja maupun tidak sengaja. Pihak yang tidak sengaja melakukan wanprestasi ini dapat terjadi karena memang tidak mampu untuk memenuhi prestasi tersebut atau juga terpaksa untuk tidak melakukan prestasi tersebut (Ahmadi, 2016). Terhadap debitur yang lalai (wanprestasi), siberhutang dapat memilih antara berbagai kemungkinan: Pertama, ia dapat meminta pelaksanaan perjanjian meskipun pelaksanaannya sudah terlambat. Kedua dapat meminta penggantian kerugian saja, yaitu kerugian yang diderita olehnya karena perjanjian tidak atau terlambat dilaksanakan, atau dilaksanakan tetapi tidak sebagaimana mestinya. Ketiga ia dapat menuntut pelaksanaan perjanjian disertai dengan penggantian kerugian yang diderita olehnya sebagai akibat terlambatnya pelaksanaan perjanjian. Keempat dalam hal suatu perjanjian yang meletakkan kewajiban timbal balik. Kelalaian darisatu pihak memberikan hak kepada pihak yang lain, untuk meminta kepada hakim supaya perjanjian tuntutan juga dapat disertai dengan permintaan penggantian kerugian (Subekti, 2005).

Dalam perjanjian kredit pada PT. Bank BRI Unit Amlapura, seorang debitur dapat dikatakan wanprestasi, apabila debitur tersebut telah berhenti membayar atau telah dilakukan tunggakan angsuran yang diwajibkan padanya. Untuk tunggakan angsuran debitur ini, kreditur akan melakukan penagihan angsuran itu beserta bunganya tanpa denda. Apabila penagihan secara damai itu belum dapat dipenuhi oleh kreditur maka kreditur memberikan jangka waktu yang pantas untuk membayar hutangnya. Ketika jangka waktu yang ditentukan debitur belum juga melunasi hutangnya dan tidak ada itikad baik dari debitur untuk melunasi hutangnya maka kreditur akan mengambil tindakan yaitu menagih jaminan umum meskipun jaminan umum tersebut tidak tercantum dalam perjanjian. Berdasarkan jaminan umum tersebut nanti akan dipergunakan untuk pelunasan hutang debitur, tetapi jika pihak debitur tidak mau menyerahkan jaminan umum yang dijaminkan itu secara sukarela, dan peringatan terakhir secara tercatat dari bank (kreditur) tidak membawa hasil yang memuaskan maka pihak kreditur akan menyerahkan urusannya pada pengadilan dan Badan Lelang Negara.

Adapun alasan debitur tidak dapat memenuhi kewajibannya dapat disebabkan dua hal yaitu:

1. Seorang debitur tidak dapat membuktikan bahwa tidak dapatnya ia melalukan prestasi adalah diluar overmacht. Artinya debitur tidak dapat membuktikan adanya overmacht, sehingga dalam hal ini debitur salah.

2. Debitur tidak dapat memenuhi prestasi kepada kreditur dikarenakan overmacht. Overmacht adalah suatu keadaan atau kejadian yang tidak dapat terduga terjadi, sehingga menghalangi seorang debitur untuk melakukan prestasi sebelum ia lalai dan keadaan tersebut tidak dapat dipersalahkan padanya (Wawancara dengan Arif Budiman, 6 Maret 2020).

Perjanjian kredit bank yang mana apabila seorang debitur tidak membayar angsuran selama tiga kali berturu-turut, maka pihak bank akan melakukan somasi dan apabila telah dilakukan somasi debitur masih mengabaikan kewajibannya serta jalan damai telah ditempubh juga tidak membawa hasil, maka 
pihak bank bisa menunjuk pengadilan untuk mengambil alih masalahnya (Wawancara dengan Arif Budiman, 6 Maret 2020).

Sebab-sebab seorang debitur lalai untuk memenuhi kewajibannya adalah sebagai berikut:

1) Kesalahan dari debitur itu sendiri, seperti seorang debitur yang kurang sehingga perusahaannya di dalam mengelola usahanya, mampu mengalami keterlambatan dalam memproduksi. Hal ini akan menjurus pada Suatu kerugian, sehingga pembayaran uang angsuran kredit tersendat-sendat. Seorang debitur yang demikian bila berlangsung lama atau terus menerus akan tidak bisa memenuhi prestasi dan selanjutnya bisa wanprestasi.

2) Sebagai fakta uraum menyebabkan terjadinya kepailitan terhadap seorang debitur yang demikian, maka kreditur biasanya secepatnya mencairkan barang jaminan.

3) Terjadinya penyimpangan penggunaan fasilitas kredit. Hal ini merupakan kesalahan debitur tidak digunakan sesuai dengan tujuan semula yang terdapat dalam perjanjian kredit.

4) Adanya itikad yang kurang baik dari debitur misalnya seorang debitur mendapat pinjaman kredit, karena adanya usur penipuan, sehingga setelah mendapatkan pinjaman kredit, debitur tersebut lalai berprestasi dengan sengaja ataupun melarikan diri, karena barang jaminan hanya berupa fidusia (Wawancara dengan Ni Wayan Somadri, 6 Maret 2020).

Apabila debitur telah melakukan wanprestasi, sehingga menimbulkan akibat hukum kreditur mengalami kerugian, debitur dapat dituntut untuk membayar ganti rugi sesuai dengan apa yang ada dalam perjanjian.

\section{Upaya Hukum yang Dilakukan Kreditur terhadap Debitur yang Tidak Dapat Melakukan Pelunasan Hutangnnya}

Dalam perjanjian kredit hendaknya para analis kredit melakukan analisa yang teliti dengan memperhatikan prinsip $5 \mathrm{C}$ dimana terdiri dari character, capacity, capital, collateral dan condition (Astuty, 2015). Tujuan analisa tersebut untuk menekan seminimal mungkin resiko terjadinya kredit macet. Selanjutnya memilah-milah permohonan kredit yang diajukan berdasarkan plafon pinjaman. Dimana untuk plafon pinjaman yang diperkirakan masih dalam batas kecil, umumnya debitur memerlukan dana yang segera.

Dalam perjanjian kredit KUR Mikro di PT Bank BRI Unit Amlapura, dimana platfond kredit yang diberikan oleh kreditur kepada debitur secara total eksposure sampai dengan Rp. 5. 000.000 (lima juta rupiah) yang diberikan kepada usaha mikro perorangan yang memiliki usaha produktif yang dimintakan penjaminan kepada penjamin. Penjaminan diberikan oleh penjamin (PT. Askrindo) kepada debitur yang tidak dapat melakukan pelunasan hutangnya atau wanprestasi. Dimana pihak kreditur terlebih dahulu melakukan upaya pendekatan kepada debitur untuk melunasi pembayaran hutangnya. dengan cara tersebut debitur belum juga bisa melakukan kewajibannya, maka secara teoretis akan berlaku ketentuan jaminan umum yang tertera dalam Pasal 1131 dan 1132 KUHPerdata.

Namun, di dalam pelaksanaanya pihak kreditur dalam pembiayaan kredit KUR Mikro menggunakan ketentuan yang dibuat oleh bank berdasarkan Surat Edaran Nose: S.8aDIR/ADK/02/2008 dimaria dalam surat edaran tersebut menentukan bahwa apabila debitur tidak dapat melakukan pelunasan hutangnya, maka pihak kreditur akan mengajukan klaim kepada pihak penjamin (PT. Askrindo). Kemudian penjamin akan mengeluarkan putusan dalam jangka waktu 15 hari penjamin kerja terhitung sejak berkas pengajuan klaim diterima secara lengkap oleh penjamin. Besar kerugian yangnanti dibayar oleh penjamin yaitu $70 \%$ x (sisa pokok kredit + bunga + denda) atau setinggitingginya sebesar $70 \%$ dari platfond kredit. Apabila semua proses pembayaran sudah dilaksanakan oleh penjamin, pihak debitur tidak bisa lepas tanggung jawab begitu saja. Hal ini dikarenakan kreditur memiliki atau mempunyai hak terhadap obyek atau usaha yang dibiayai, sehingga pihak debitur berkewajiban tetap untuk melunasi sisa pembayaran yang belum dilakukan namun bukan kepada pihak bank melainkan kepada penjamin (PT. Askrindo) yang diperantarai oleh pihak Bank.

Sehingga pihak kreditur nantinya berkewajiban tetap untuk menagih pembayaran hutang debitur. Apabila debitur tidak juga bisa melakukan pelunasan hutangnya dan tidak ada itikad baik dari debitur. maka bank dapat melakukan upaya hukum dengan menyerahkan masalah tersebut ke Pengadilan Negeri melalui pengajuan gugatan. Hal ini dapat dilakukan karena dalam surat edaran tidak ditentukan mengenai upaya hukum, sehingga kreditur berdasarkan ketentuan pasal 1338 KUHPerdata yaitu suatu perjanjian/kontrak yang dibuat secara sah oleh para pihak berlaku sebagai Undang-Undang, pihak 
kreditur dapat melakukan upaya hukum dengan menyerahkan masalah tersebut ke Pengadilan Negeri melalui pengajuan gugatan, karena kreditur berhak menuntut jaminan umum dari debitur sesuai ketentuan Pasal 1131 KUHPerdata sebagai jaminan umum untuk pelunasan hutang debitur apabila tidak dapat melakukan pelunasan hutangnya.

Menurut Ni Wayan Somadri, Mantri Kredit PT. Bank BRI Unit Amlapura, Akibat hukum apabila terjadi kredit macet bank hendaknya melakukan upaya- upaya hukum seperti mengidentifikasi sedini mungkin terjadinya kredit macet, melakukan penyelamatan terhadap kredit dan mengintensifkan penagihan. Jika dengan upaya tersebut debitur tetap tidak dapat melakukan pelunasan hutangnya, penyelesaian selanjutnya dilakukan secara musyawarah mufakat untuk menemukan jalan keluar yang dikehendaki kedua belah pihak (win-win solution). Selain upaya hukum tersebut, bank dapat melakukan upaya hukum litigasi dengan mengajukan gugatan ke Pengadilan Negeri. Namun dalam pelaksanaan pembiayaan kredit KUR Mikro di PT. Bank BRI Unit Amalpura, pihak kreditur sebelum melakukan upaya hukum menyerahkan permasalahan kepada Pengadilan Negeri lewat pengajuan gugatan, dalam surat edaran sudah ada penjaminan dari penjamin sebesar $70 \%$ dari platfon kredit dan $30 \%$ dari pihak bank, namun debitur tetap berkewajiban untuk melunasi utangnya sampai debitur dinyatakan tidak lagi memiliki utang. Apabila sampai dengan batas waktu yang diberikan debitur tidak juga melunasi utangnya, kreditur memiliki hak untuk meminta jaminan umum sesuai ketentuan pasal $1131 \mathrm{KUH}$ Perdata dengan mengajukan gugatan perdata ke Pengadilan Negeri (Wawancara dengan Ni Wayan Somadri, 9 Maret 2020).

\section{SIMPULAN DAN SARAN}

\section{Simpulan}

Penelitian ini berhasil mengungkap beberapa hal yang dirangkum dalam simpulan berikut. Pertama, pada PT. Bank BRI Kantor Unit Amalapura, pemberian kredit KUR Mikro kepada debitur dijamin oleh penjamin (PT Askrindo) sebesar 70\% dari platfond kredit dan 30\% dari bank apabila debitur wanprestasi dan tidak ada jamnian tambahan sesuai dengan ketentuan Surat Edaran Nose: S.8aDIR/ADK/02/2008. Namun setelah penjaminan diberikan oleh penjamin kepada kreditur, nantinya hak untuk menagih pelunasan utang debitur beralih kepada penjamin (Subrogasi), sehingga debitur tetap memiliki kewajiban untuk melunasi utangnya. Yang kedua, upaya hukum yang dilakukan oleh kreditur terhadap debitur yang tidak dapat melakukan pelunasan hutangnya dalam hal terjadi kredit macet dengan mengidentifikasi sedini mungkin terjadinya kredit macet dan mengintensifkan penagihan, melakukan musyawarah mufakat untuk menemukan jalan keluar yang dikehendaki kedua belah pihak (win-win solution). Selain upaya hokum tersebut, sesuai dengan ketentuan pasal 1131 KUHPerdata tentang jaminan umum dapat digunakan sebagai pelunasan utang debitur dengan mengajukan gugatan perdata ke Pengadilan Negeri.

\section{Saran}

Berikut adalah beberapa rekomendasi dari hasil kajian ini. Pertama, PT. Bank BRI Unit Amlapura dalam pemibayaan kredit KUR Mikro apabila debitur melakukan wanprestasi, disarankan menerapkan asas spesialitet yaitu adanya penunjukan benda jaminan secara khusus untuk digunakan jaminan, baik benda bergerak maupun tidak bergerak dan diuraikan secara jelas dalam perjanjian untuk menghindari adanya kreditur konkuren. Yang kedua, untuk kepastian hukum dan memposisikan PT. Bank BRI Unit Amlapuraa pada posisi menguntungkan dalam pembiayaan kredit KUR Mikro harus adanya penunjukan benda jaminan secara khusus maka hak eksekutorial atas benda jaminan dapat meminimalisasi kredit macet yang disebabkan debitur wanprestasi.

\section{DAFTAR PUSTAKA}

Ackah, J., \& Vuvor, S. (2011). The Challenges faced by Small \& Medium Enterprises (SMEs) in Obtaining Credit in Ghana. In Journal of Small Business Management. Blekinge Tekniska Hogskola.

Ahmadi, M. (2016). Hukum Kontrak dan Perancangan Kontrak (7th ed.). PT. Raja Grafindo Persada. Anggraeni, F. D., Hardjanto, I., \& Hayat, A. (2013). Pengembangan Usaha Mikro, Kecil, dan Menengah (UMKM) Melalui Fasilitasi Pihak Eksternal dan Potensi Internal. Jurnal Administrasi Publik (JAP), 1(6), 1086-1095. 
Apriani, R. (2018). Upaya Penyelesaian Wanprestasi dari Kredit Usaha Rakyat yang Diasuransikan pada PT Askrindo. Yurispruden, 1(2), 136-148. https://doi.org/10.1017/CBO9781107415324.004

Aryastini, I. G. A. M., Wairocana, I. G. N., \& SarjanA, I. M. (2018). Perlindungan Hukum bagi Usaha Mikro, Kecil dan Menengah (UMKM) dalam Penerimaan Bantuan Permodalan dari Perusahaan Modal Ventura dengan Surat Pernyataan Jaminan Kepastian Pencairan (SPJK P) Bilyet Giro. Acta Comitas, 1(1), 185-200.

Astuty, H. S. (2015). Prinsip 6C (Character, Capacity, Capital, Condition of Economy, Collateral Dan Constraint) dalam Wirausaha Mahasiswa. Jurnal Economia, 11(1), 56-71. https://doi.org/10.21831/economia.v11i1.7756

Faulkner, A., Lange, B., \& Lawless, C. (2012). Introduction: Material Worlds: Intersections of Law, Science, Technology, and Society. Journal of Law and Society, 39(1), 1-19. https://doi.org/10.1111/j.1467-6478.2012.00567.x

Ibrahim, J., \& Sewu, L. (2007). Hukum Bisnis Dalam Pesepsi Manusia Modern. Refika Aditama.

Kraft, J. R., Baum, W. M., \& Burge, M. J. (2002). Group C hoice and Individual Choices: Modeling Human Social Behavior with the Ideal Free Distribution. Behavioural Processes, 57(2-3), 227240. https://doi.org/10.1016/S0376-6357(02)00016-5

Mercuro, N. (1986). Research in Law and Economics: Normative Law and Economics. Journal of Economic Issues, 20(4), 1146-1151. https://doi.org/10.1080/00213624.1986.11504584

Pramudyawardani, C. M. (2010). Penyelesaian Wanprestasi dalam Perjanjian Kredit dengan Jaminan Hak Tanggungan di "Mitra Mayapada Usaha” di Surakarta. Universitas Sebelas Maret.

Ramandhana, D. Y., Jayawarsa, A. A. K., \& Aziz, I. S. A. (2018). Pengaruh Inflasi, Suku Bunga BI Rate, Pertumbuhan Ekonomi, Non Performing Loan (NPL) dan Capital Adequacy Ratio (CAR) terhadap Penyaluran Kredit Usaha Rakyat. Warmadewa Economic Development Journal 1, 1(1), $30-40$.

Solikatun, Supono, Masruroh, Y., \& Zuber, A. (2014). Kemiskinan dalam Pembangunan. Jurnal Analisa Sosiologi, 3(1), 70-90. https://doi.org/10.1017/CBO9781107415324.004

Subekti. (2005). Hukum Perjanjian. Intermasa.

Wilee, C. T., \& Davis, S. F. (1976). Level of Self-Esteem and Size of Human Figure Drawing As A Function of Group Vs Individual Administration. Psychological Reports, 39(1), 130. https://doi.org/10.2466/pr0.1976.39.1.130 